\title{
IMPLEMENTASI EXAMPLES NON EXAMPLES UNTUK MENINGKATKAN KETERAMPILAN BERPIKIR KRITIS DAN PRESTASI BELAJAR BAHASA INGGRIS
}

\author{
NURYANTI \\ SMAN 1 Purwanegara, Jawa Tengah \\ Email : nuryanti13@gmail.com
}

\begin{abstract}
ABSTRAK
Penelitian ini bertujuan mengimplementasikan model pembelajaran Examples Non Examples untuk meningkatkan keterampilan berpikir kritis dan prestasi belajar dalam memahami isi teks bahasa Inggris siswa XII IPA 1 SMAN 1 Purwanegara semester 1 tahun pelajaran 2018/2019. Penelitian dilakukan melalui dua siklus yang terdiri dari empat tahap yaitu: perencanaan, pelaksanaan, pengamatan, dan refleksi. Teknik pengumpulan data yang digunakan adalah teknik observasi, tes dan dokumentasi. Penerapan model pembelajaran Examples Non Examples telah meningkatkan keterampilan berpikir kritis siswa yang ditunjukkan dari hasil observasi siswa dengan kategori tinggi disiklus I sejumlah 13 siswa (62\%) dan meningkat lagi di siklus II menjadi 18 siswa $(85,7 \%)$. Hal ini berdampak pula pada prestasi belajar siswa juga meningkat, disiklus I nilai rata-rata 72,7 dengan ketuntasan belajar 57,2\% dan disiklus II mencapai nilai rata-rata 80,7 sehingga memenuhi ketuntasan belajar klasikal 80,9\%. Dengan demikian disimpulkan bahwa implementasi model pembelajaran Examples Non Examples dapat meningkatkan keterampilan berpikir kritis dan prestasi belajar dalam memahami isi teks bahasa Inggris siswa XII IPA 1 SMAN 1 Purwanegara semester 1 tahun pelajaran 2018/2019. Kata kunci: Examples Non Examples, Berpikir Kritis, Prestasi Belajar
\end{abstract}

\section{PENDAHULUAN}

Salah satu standar kompetensi dalam mata pelajaran Bahasa Inggris di kelas XII semester gasal adalah membaca (Reading) yang mengharuskan siswa untuk dapat memahami makna teks fungsional pendek dan esei sederhana berbentuk narrative, explanation, dan discussion dalam konteks untuk mengakses ilmu pengetahuan. Oleh karena itu materi yang diajarkan juga kebanyakan berisi tentang teks bahasa Inggris yang kosakatanya semakin kompleks, sehingga siswa membutuhkan banyak waktu untuk memahami isi teks tersebut. Hal ini memberikan dampak bagi siswa yaitu banyak dari mereka yang kurang berminat terhadap materi ini akhirnya siswa banyak yang enggan untuk memahami isi teks terutama dalam bahasa Inggris. Begitu pula dengan cara penyampaian guru yang cenderung monoton menguasai kelas dan konvensional membuat banyak siswa yang kurang leluasa dalam menyampaikan ide-ide kritis mereka.

Tujuan penyelengaraan pengajaran Bahasa Inggris khususnya komponen membaca ditingkat SMA/MA menurut Depdiknas dalam Santi (2009:5) adalah untuk membentuk siswa yang memiliki kemampuan memahami teks tulis berupa teks fungsional pendek (pengumuman, label, dan lain lain), yang ditemukan dalam berbagai konteks situasi dan berbagai jenis teks (naratif, deskriptif, dan lain lain), yang menggunakan ragam bahasa tulis. Dalam realita, untuk memenuhi tujuan tersebut, kebanyakan guru masih menggunakan gaya konvensional dalam mengajar contohnya metode ceramah yang akhirnya berimbas pada menurunnya ide berpikir kritis siswa. Keharusan memahami teks dengan model pengajaran yang konvensional ini membuat siswa menjadi jenuh dan bosan yang akhirnya juga berpengaruh dalam prestasi belajar mereka disekolah.

Hasil pengamatan sebelum penerapan model pembelajaran yang baru dalam mempelajari teks bahasa Inggris diawal siklus dapat kita lihat dari tabel dibawah ini: 
Tabel 1. Ketercapaian Keterampilan Berpikir Kritis dan Prestasi Belajar Siswa Pra Siklus

\begin{tabular}{|c|c|c|c|c|c|c|}
\hline No & $\begin{array}{c}\text { Keterampilan } \\
\text { Berpikir Kritis } \\
\text { Siswa }\end{array}$ & $\begin{array}{c}\text { Jumlah } \\
\text { Siswa }\end{array}$ & $\%$ & $\begin{array}{c}\text { Tes Prestasi } \\
\text { Belajar Siswa }\end{array}$ & Hasil & Keterangan \\
\hline 1 & Rendah & 3 & 14,2 & Nilai Tertinggi & 88 & \\
\hline 2 & Sedang & 13 & 62 & Nilai Terendah & 35 & 6 siswa \\
\hline 3 & Tinggi & 5 & 23,8 & $\begin{array}{c}\text { Ketuntasan } \\
\text { belajar }\end{array}$ & $29 \%$ & \\
\hline & Jumlah & 21 & 100 & Nilai Rata-Rata & 67,86 & \\
\hline
\end{tabular}

Sumber data: Observasi dan Nilai Harian Siswa Pra Siklus

Dari data diatas dapat kita simpulkan bahwa metode mengajar konvensional guru dari pengamatan pra siklus baru terdapat 5 siswa $(23,8 \%)$ yang mampu berpikir kritis untuk mengeluarkan ide mereka dalam mengikuti proses pembelajaran di kelas. Selain itu dari hasil nilai prestasi belajar yang diperoleh dari 21 siswa baru terdapat 6 siswa atau 29\% yang telah mencapai ketuntasan minimal. Sangat jauh dari kriteria untuk memenuhi ketuntasan belajar klasikal $80 \%$ dikelas dalam pembelajaran Bahasa Inggris.

Menyikapi kondisi tersebut, perubahan metode mengajar guru sangat diperlukan agar kondisi dalam belajar mengajar dikelas sesuai dengan hasil yang akan diharapkan. Salah satunya dengan menggunakan model pembelajaran Examples Non Examples. Menurut Slavin dalam Chotimah (2007:1) Examples Non Examples adalah model pembelajaran yang menggunakan contoh-contoh. Contoh-contoh ini dapat diperoleh dari kasus atau gambar yang relevan dengan kompetensi dasar yang diajarkan ke siswa. Berdasarkan referensi dari beberapa ahli, peneliti menyimpulkan langkah-langkah model pembelajaran Examples Non Examples sebagai berikut: Pertama guru mempersiapkan gambar-gambar yang sesuai dengan tujuan pembelajaran. Kemudian guru menayangkan gambar-gambar menggunakan layar proyeksi. Setelah itu guru memberi petunjuk dan memberi kesempatan pada siswa untuk memperhatikan atau menganalisa gambar tersebut. Berikutnya siswa secara berkelompok terdiri dari 3-5 siswa berdiskusi tentang hasil analisa terhadap gambar yang ditayangkan tersebut dan mencatat pada buku catatan. Selanjutnya tiap kelompok diberi kesempatan membacakan hasil diskusinya didepan kelas dan dari hasil diskusi siswa tersebut, guru menjelaskan materi sesuai dengan tujuan yang ingin dicapai. Di akhir guru bersama dengan siswa membuat kesimpulan.

Model pembelajaran ini memiliki banyak kelebihan antara lain: 1) Siswa memiliki pemahaman dari sebuah definisi dan selanjutnya digunakan untuk memperluas pemahaman konsepnya dengan lebih mendalam dan lebih lengkap; 2) Mengantarkan siswa agar terlibat dalam sebuah penemuan dan mendorong mereka untuk membangun konsep secara progresif melalui pengalaman dari gambar-gambar yang ada; 3) Siswa akan mendapatkan dua konsep sekaligus, karena ada dua gambar yang diberikan dimana salah satu gambar sesuai dengan materi yang dibahas dan gambar lainnya tidak; 4) Membuat siswa lebih kritis dalam menganalisa gambar; 5) Siswa mendapatkan pengetahuan yang aplikatif dari materi berupa contoh gambar; 6) Siswa diberi kesempatan untuk mengemukakan pendapatnya secara pribadi. (Imas Kurniasih, 2015:33)

Dari keunggulan model pembelajaran tersebut sangat diharapkan keterampilan berpikir dan prestasi belajar siswa juga akan meningkat. Keterampilan berpikir kritis sangat penting dimiliki oleh siswa, karena memungkinkan siswa untuk dapat menyelesaikan masalah sosial, keilmuan dan permasalahan praktis secara efektif. Menurut pendapat Paul dan Elder (2008:4) dapat kita simpulkan bahwa berpikir kritis merupakan proses intelektual dan penuh konsep akan keterampilan yaitu mengaplikasikan; menganalisa; mensintesa; mengevaluasi darimana suatu informasi diperoleh; atau men-generalisasi hasil dari proses observasi, pengalaman, refleksi, penalaran, atau komunikasi sebagai dasar untuk dipercaya dan apa yang akan dilakukan. Pengambilan data untuk keterampilan berpikir kritis dapat dilakukan melalui 
observasi atau pengamatan didalam kelas berkolaborasi dengan guru lain yang mata pelajarannya sama.

Adapun dari cara berpikir kritis ini dapat memberikan pengaruh dalam prestasi belajar siswa khususnya memahami makna teks bahasa Inggris. Menurut kamus Besar bahasa Indonesia (2001:895) prestasi belajar adalah penguasaan pengetahuan atau keterampilan yang dikembangkan melalui mata pelajaran, lazimnya ditunjukan dengan nilai yang diberikan oleh guru. Ditambahkan lagi menurut Bloom (dalam Sunarto, 2012) bahwa prestasi belajar dibedakan menjadi tiga aspek yaitu Kognitif, Afektif dan Psikomotor dan ini semua wajib di kuasai oleh siswa. Sebagai bukti telah dikuasainya kemampuan-kemampuan baru oleh siswa dinyatakan dengan nilai yang berupa angka-angka. Makin tinggi nilai yang diperoleh peserta didik berarti makin tinggi pula tingkat kemampuan-kemampuan baru yang dikuasainya. Dalam penelitian tindakan kelas ini, yang dimaksud dengan nilai prestasi belajar mata pelajaran bahasa Inggris wajib adalah nilai yang diperoleh siswa kelas XII IPA 1 SMAN 1 Purwanegara pada semester gasal tahun pelajaran 2018/2019 setelah melalui tes tertulis disiklus I dan tes siklus II.

\section{METODE PENELITIAN}

Penelitian ini menggunakan rancangan penelitian tindakan yang terfokus dalam kegiatan di kelas yang dilaksanakan di XII IPA 1 SMAN 1 Purwanegara semester 1 tahun ajaran 2018/2019 dibulan Juli 2018 sampai dengan bulan Oktober 2018 dengan Standar Kompetensi memahami makna teks fungsional pendek dan esei sederhana berbentuk narrative, explanation, dan discussion dalam konteks kehidupan sehari-hari dan untuk mengakses ilmu pengetahuan.

Penelitian dilaksanakan dengan dua siklus yaitu siklus I dan siklus II. Tiap siklus melalui tahapan sebagai berikut : perencanaan, pelaksanaan, pengamatan, dan refleksi dengan implementasi model pembelajaran Examples No Examples. Hanya di tiap siklus mendapatkan perbedaan perlakuan dalam sistem pembentukan kelompok besar dan kecil, seperti yang ditunjukkan didalam bagan berikut ini:

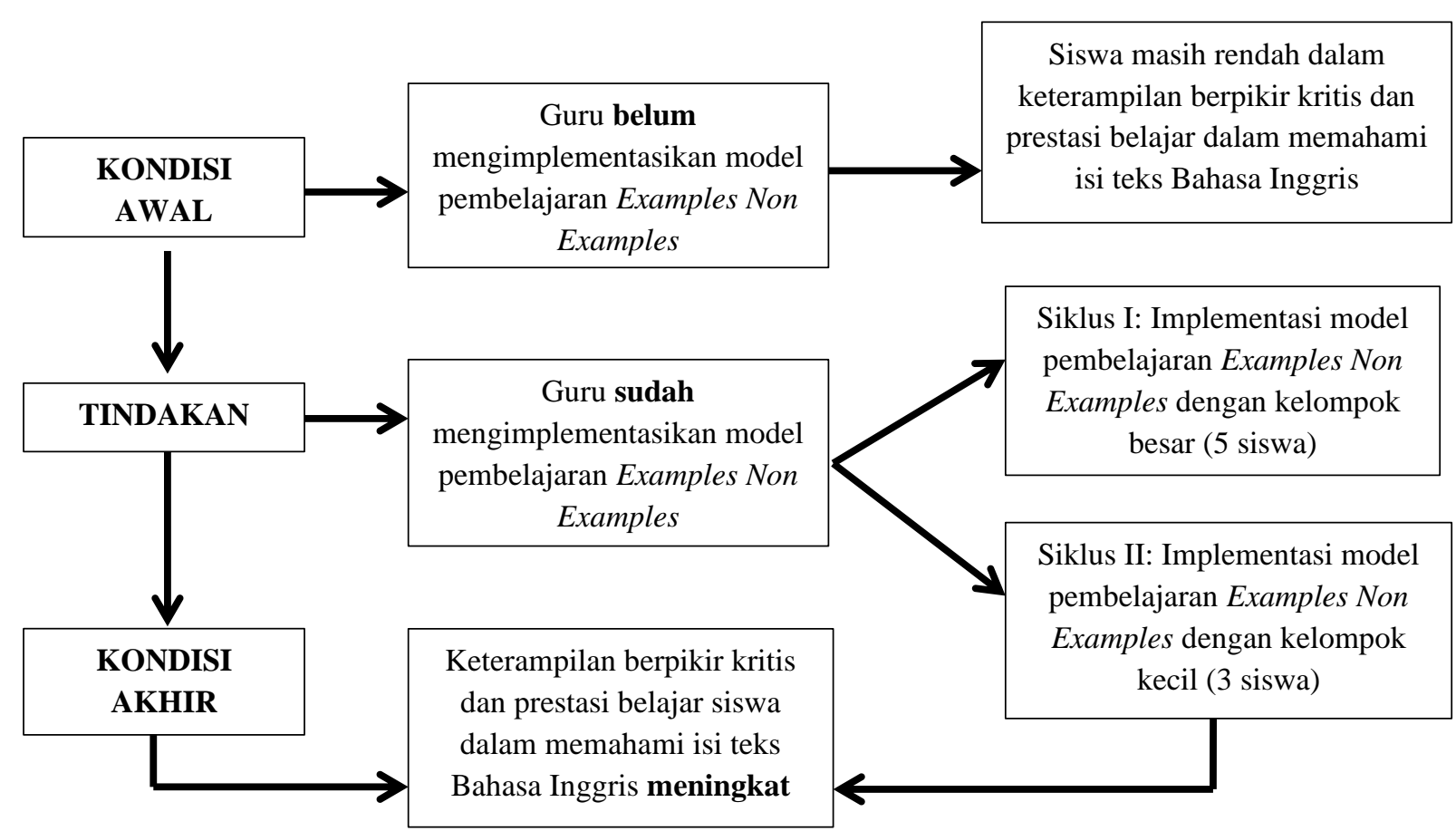

Gambar 1. Bagan Alur Kerangka Berpikir 
Sedangkan teknik dan alat pengumpulan data menggunakan teknik observasi/pengamatan bersama guru sejawat (kolaborator) dengan menggunakan Lembar Observasi Keterampilan Berpikir Kritis Siswa untuk mengamati perilaku siswa selama berlangsungnya proses pembelajaran menggunakan model pembelajaran Examples Non Examples serta Lembar Pengamatan Alat Penilaian Kemampuan Guru Merencanakan Tindakan yang menilai kesiapan peneliti dalam merencanakan tindakan selama penelitian dalam bentuk Rencana Pelaksanaan Pengajaran dan Alat Penilaian Kemampuan Guru Melaksanakan Tindakan yang menilai kemampuan peneliti dalam implementasi model pembelajaran Examples Non Examples selama proses pembelajaran didalam kelas. Teknik selanjutnya adalah teknik tes yang berupa perangkat untuk menilai prestasi belajar siswa dengan bentuk tes tertulis berupa kisi-kisi soal, norma penilaian, kunci jawaban soal, lembar jawab tes, butir soal tes prestasi belajar siswa yang terdiri dari: 20 soal pilihan ganda, 10 soal isian singkat dan 5 soal uraian. Tes ini untuk mengetahui pencapaian siswa dalam aspek kognitif. Terakhir adalah menggunakan teknik dokumentasi sebagai bukti fisik adanya penelitian tindakan kelas ini yang berupa dokumen keterampilan berpikir kritis dan prestasi belajar siswa dari kondisi awal, siklus I dan siklus II, serta foto setiap tindakan yang diambil di tiap-tiap siklus.

Peneliti juga menentukan indikator keberhasilan sebagai target kondisi akhir yang diharapkan tercapai. Indikator keberhasilan dalam penelitian ini adalah apabila implementasi model pembelajaran Examples Non Examples dalam keterampilan berpikir kritis siswa dinyatakan berhasil jika $80 \%$ atau 18 siswa dari 21 siswa mencapai kriteria yang tinggi dan prestasi belajar siswa dinyatakan berhasil jika nilai rata-rata tes prestasi belajar 75,00 dengan ketuntasan belajar $80 \%$ atau 18 siswa dari 21 siswa tuntas dalam belajar.

\section{HASIL DAN PEMBAHASAN}

\section{A. Hasil Penelitian}

\section{Siklus I Pertemuan Pertama}

Bahasa Inggris setiap minggunya diajarkan selama 4 jam disetiap kelas, oleh karena itu pertemuan pertama di siklus I ini diadakan dua kali tatap muka. Tatap muka pertama dilaksanakan hari Senin, 23 Juli 2018 dan tatap muka kedua dilaksanakan hari Jumat, 24 Juli 2018. Dalam pelaksanaan tatap muka pertama, guru masuk kedalam kelas bersama kolaborator untuk menagajarkan materi teks Narrative. Guru mengucapkan salam dan menyiapkan siswa untuk mengikuti proses pembelajaran seperti berdoa bersama, absensi, menyiapkan buku pelajaran dan mengkondisikan suasana belajar yang menyenangkan dan memotivasi siswa dengan cara mengajukan pertanyaan-pertanyaan yang mengaitkan pengetahuan sebelumnya dengan materi yang akan dipelajari yakni teks Narrative. Setelah itu guru menjelaskan model pembelajaran yang akan digunakan yaitu Examples Non Examples serta tujuan pembelajaran dan kompetensi dasar yang akan dicapai kepada siswa yaitu mampu memahami, mengurutkan dan menjelaskan isi cerita dari gambar-gambar yang diberikan oleh guru menjadi teks Narrative yang benar dan urut.

Kegiatan inti yang berbentuk eksplorasi dalam pembelajaran, guru mengajak siswa untuk memahami urutan cerita dari setiap gambar acak yang ditayangkan melalui layar proyeksi. Setelah itu guru memberitahukan isi cerita yang sesuai dan benar tentang jalan cerita dari gambar bercerita tersebut dalam bentuk teks. Kemudian guru menjelaskan secara detil mengenai teks Narrative disertai perbandingan contoh-contoh teks yang Narrative dengan yang bukan teks Narrative. Agar siswa lebih paham materinya, dalam bentuk kolaborasi guru membagi siswa menjadi beberapa kelompok besar yang terdiri dari 5 siswa. Setiap kelompok mendiskusikan Lembar Kerja Siswa yang diberikan oleh guru. Dibagian konfirmasi, setiap kelompok melaporkan hasil diskusi didepan kelas dan kelompok yang lain menanggapi dan mengoreksi hasil jawaban kelompok tersebut. Setelah selesai, guru memberikan umpan balik mengenai proses pembelajaran yang telah dilakukan dan memberikan tugas kepada setiap siswa untuk mencari contoh teks Narrative dari berbagai 
sumber (majalah, surat kabar, internet) dan menuliskan pesan moral yang ada dalam teks Narrative tersebut. Diakhir pembelajaran guru memberikan salam penutup. Sedangkan ditatap muka kedua, guru mengajarkan materi teks Explanation dengan proses pembelajaran yang sama dengan tatap muka pertama.

\section{Siklus I Pertemuan Kedua}

Pertemuan kedua juga dilaksanakan dua kali tatap muka. Tatap muka pertama pada hari Senin, 6 Agustus 2018 dan tatap muka kedua pada hari Selasa, 7 Agustus 2018. Guru beserta kolaborator masuk kelas. Tatap muka pertama dipertemuan kedua ini di awali dengan guru memberikan salam, kemudian guru membahas dan mengumpulkan tugas siswa yang diberikan pada pertemuan sebelumnya. Guru mengajukan pertanyaan-pertanyaan apersepsi yang mengaitkan pengetahuan sebelumnya yaitu tentang teks Narrative dan teks Explanation.

Dalam kegiatan inti berbentuk eksplorasi, guru memberikan penguatan tentang materi teks Narrative dan Explanation dan perbedaanya dengan disertai contoh-contoh. Kemudian mengajak siswa berkolaborasi dengan cara membentuk kelompok besar yang terdiri dari 5 siswa. Guru memberikan Lembar Kerja Siswa kepada tiap kelompok untuk didiskusikan bersama. Dibagian konfirmasi, setiap kelompok memaparkan dan menjelaskan hasil diskusi mereka didepan kelas dan kelompok lain menanggapi hasilnya. Setelah selesai, guru memberikan umpan balik dan penguatan agar siswa dapat mempersiapkan diri mengikuti tes evaluasi materi teks Narrative dan Explanation dipertemuan berikutnya.

Mengawali tatap muka kedua, guru setelah mengucapkan salam dan berdoa bersama, mempersiapkan siswa untuk mengikuti tes atau evaluasi prestasi belajar siswa dalam memahami isi teks bahasa Inggris (tes dilaksanakan secara individu). Setelah waktu yang ditentukan selesai, masing-masing siswa mengumpulkan hasil tes kepada guru. Guru mengadakan refleksi pembelajaran akan hasil tes siswa dan mengakhiri pertemuan dengan mengucapkan salam. Hasil dari tes prestasi belajar siswa disiklus I dapat dilihat dari tabel di bawah ini:

Tabel 2 Hasil Tes Prestasi Belajar Siswa Siklus I

\begin{tabular}{|c|c|c|}
\hline No & Uraian & $\begin{array}{c}\text { Hasil Tes Prestasi Belajar } \\
\text { Siswa Siklus I }\end{array}$ \\
\hline 1 & Nilai Tertinggi & 95,38 \\
\hline 2 & Nilai Terendah & 40,00 \\
\hline 3 & Rata-Rata & 72,7 \\
\hline 4 & Ketuntasan Belajar & $57,2 \%$ \\
\hline
\end{tabular}

Dari data diatas dapat kita simpulkan secara kualitatif bahwa rata-rata dari tes prestasi belajar siswa dalam memahami isi teks bahasa Inggris materi teks Narrative dan Explanation di siklus I adalah 72,7. Untuk nilai tertinggi 95,38 sedangkan nilai terendah 40,00. Dapat kita lihat juga prosentase tidak tuntas sebesar $42,8 \%$ atau 9 siswa tidak tuntas, sedangkan prosentase ketuntasan $57,2 \%$ hanya 12 siswa tuntas. Sedangkan observasi atau pengamatan dengan kolaborator tentang keterampilan berpikir kritis siswa didapatkan hasil sebagai berikut: 
Tabel 3 Hasil Analisis Keterampilan Berpikir Kritis Siswa Siklus I

\begin{tabular}{|c|c|c|c|cc|}
\hline Hasil Analisis & Frekuensi & Skor & \% & Skor Tengah & Frekuensi \\
\hline TINGGI & 13 & $8-10$ & 62 & $9 \times 13$ & $=117$ \\
\hline SEDANG & 3 & $4-7$ & 14,2 & $5,5 \times 3$ & $=16,5$ \\
\hline RENDAH & 5 & $1-3$ & 23,8 & $2 \times 5 \quad=10$ \\
\hline \multicolumn{3}{|c|}{ JUMLAH } & $\mathbf{1 4 3 , 5}$ \\
\hline RATA- RATA & 6,833 \\
\hline & KATEGORI & SEDANG
\end{tabular}

Berdasarkan tabel hasil analisis keterampilan berpikir kritis siswa siklus I diatas kita memperoleh data sebagai berikut: siswa dengan keterampilan berpikir kritis kategori tinggi sebanyak 13 siswa atau 62\%; siswa dengan keterampilan berpikir kritis kategori sedang sebanyak 3 siswa atau 14,2\%; siswa dengan keterampilan berpikir kritis kategori rendah sebanyak 5 siswa atau 23,8\%; sedangkan rata-rata keterampilan berpikir kritis di siklus I adalah 6,833. Berdasarkan data rata-rata dari keterampilan berpikir kritis siswa dalam siklus I masuk kategori sedang.

Peneliti dan kolaborator melakukan refleksi dari hasil yang diperlihatkan disiklus I. Berdasarkan lembar observasi keterampilan berpikir kritis siswa dalam belajar menggunakan implementasi model pembelajaran Examples Non Examples ini, ada beberapa aspek yang masih kurang menonjol. Diantaranya siswa masih belum mampu menjelaskan isi materi dengan detil; siswa belum mampu membuat kesimpulan; siswa belum mampu menerangkan hasil diskusi dan siswa kurang mampu menilai hasil pengamatan. Sedangkan dari data analisis tes prestasi belajar siswa dalam memahami isi teks bahasa Inggris, banyak siswa masih kesulitan dalam memilih jawaban yang tepat terutama untuk soal materi teks Explanation yang membutuhkan banyak pengetahuan umum. Dalam jenis soal pilihan ganda, siswa masih merasa sulit dalam menjawab soal yang menanyakan informasi rinci dan yang menanyakan tentang makna kata. Untuk jenis soal isian singkat, siswa masih juga kesulitan dalam menentukan kosakata yang tepat dalam melengkapi kalimat yang ada dalam paragraph. Sedangkan dalam soal uraian, siswa juga kesulitan dalam menentukan jawaban dari pertanyaan tentang informasi rinci yang berupa alasan. Sehingga indikator keberhasilan disiklus I masih belum tercapai. Oleh karena itu, peneliti dan kolaborator memutuskan untuk mengadakan perbaikan di siklus II dengan tindakan masih menerapkan model pembelajaran Examples Non Examples. Hanya perlu diadakan perbaikan dalam hal pembagian kelompok yang semula terdiri dari 5 siswa menjadi 3 siswa disetiap kelompok diskusi. Hal ini merujuk pada keunggulan menggunakan kelompok kecil menurut Mulyasa dalam Suwarna (2006:79) antara lain: kelompok menjadi kaya dengan ide dan informasi untuk mendapatkan hasil yang lebih baik, siswa termotivasi oleh kehadiran teman, mengurangi sifat pemalu dari siswa, siswa merasa terikat untuk melaksanakan keputusan kelompok, meningkatkan pemahaman diri siswa, melatih bisa untuk berpikir kritis, melatih siswa untuk mengemukakan pendapat dan mengembangkan jiwa sosial pada dirinya.

\section{Siklus II Pertemuan Pertama}

Pelaksanaan kegiatan implementasi model pembelajaran Examples Non Examples disiklus II untuk pertemuan pertama dilaksanakan dua kali. Tatap muka pertama pada hari Senin, 27 Agustus 2018 dan tatap muka kedua dilaksanakan pada hari Selasa, 28 Agustus 2018. Pelaksanaan tatap muka pertama, guru bersama dengan kolaborator masuk kelas dan mempersiapkan siswa untuk menerima materi dengan cara memberi salam, berdoa, mengabsen siswa, menyiapkan buku pelajaran dan mengkondisikan suasana belajar yang menyenangkan. Guru memberikan pertanyaan apersepsi yang merujuk pada materi yang akan diberikan yaitu teks Formal Letter. Guru menerangkan odel pembelajaran yang akan dipakai 
yaitu Examples Non Examples dan menjelaskan tujuan pembelajaran dan kompetensi dasar yang akan dicapai yaitu siswa mampu membaca, memahami dan menulis isi teks Formal Letter.

Dalam eksplorasi dibagian kegiatan inti, Guru menayangkan gambar-gambar yang berisi contoh-contoh teks Formal Letter melalui layar proyeksi dan meminta siswa untuk menganalisa dan memahami contoh-contoh gambar agar dapat menentukan jenis teksnya. Selanjutnya guru menjelaskan tentang format teks Formal Letter dan bagaimana cara membuatnya secara detil. Siswa berkolaborasi dengan teman yang lain dalam bentuk kelompok kecil yang terdiri dari 3 siswa. Kemudian guru membagikan Lembar Kerja Siswa sebagai bahan diskusi tentang teks Formal Letter kepada masing-masing kelompok. Guru membimbing dan membantu siswa apabila ada kesulitan. Setelah selesai berdiskusi dibagian konfirmasi setiap kelompok unjuk hasil kerja mereka didepan kelas dan kelompok yang lain memberikan tanggapan. Sebelum menutup pelajaran guru memberi umpan balik dan kesimpulan mengenai proses pembelajaran hari itu kemudian mengucapkan salam penutup. Begitu pula dalam tatap muka kedua, guru melakukan proses belajar mengajar dengan metode tetapi berbeda materi yaitu teks Discussion.

\section{Siklus II Pertemuan Kedua}

Pertemuan kedua siklus II ini, juga dilakukan dua kali tatap muka. Tatap muka pertama pada hari Senin, 3 September 2018 dan tatap muka kedua pada hari Selasa, 4 September 2018. Proses pembelajaran ditatap muka pertama diawali dengan guru dan kolaborator masuk kelas kemudian guru memberikan salam dan mengecek kehadiran siswa. Setelah itu, memberikan pertanyaan apersepsi tentang materi yang telah dibahas sebelumnnya yaitu teks Formal Letter dan Discussion. Dalam kegiatan inti guru melakukan eksplorasi dengan cara menjelaskan materi melalui contoh-contoh teks yang beragam agar siswa dapat membedakan mana teks Formal Letter dan teks Discussion. Kemudian meminta siswa untuk berkolaborasi dengan siswa lain dalam bentuk kelompok kecil yang terdiri dari 3 siswa untuk mendiskusikan Lembar Kerja Siswa yang diberikan oleh guru untuk dikerjakan secara kelompok. Setelah selesai berdiskusi, siswa mengkonfirmasikan hasil diskusi kelompok mereka didepan kelas dan ditanggapi oleh kelompok lainnya. Guru memberikan penguatan diakhir pembelajaran dengan menyimpulkan hasil belajar hari itu bersama siswa dan mengingatkan siswa untuk belajar mengenai materi hari itu karena dipertemuan berikutnya akan diadakan tes prestasi belajar, selanjutnya memberikan salam penutup.

Pertemuan ditatap muka kedua masih melibatkan kolaborator dan guru dikegiatan dalam kelas. Guru dan kolaborator masuk kelas, memberikan salam dan mengecek kehadiran siswa setelah itu mempersiapkan siswa untuk mengjalani evaluasi berupa tes prestasi belajar dalam memahami teks bahasa Inggris. Tes ini dilakukan secara individu didalam kelas. Setelah waktu yang telah ditentukan selesai, guru mengambil lembar jawab tes prestasi belajar dari siswa. Guru menyampaikan kepada siswa untuk mempelajari materi pertemuan berikutnya tentang Expressions in English, selanjutnya guru menutup pelajaran. Adapun hasil dari tes prestasi belajar siswa dapat kita lihat dari tabel berikut:

Tabel 4 Hasil Tes Prestasi Belajar Siswa Siklus II

\begin{tabular}{|l|l|c|}
\hline No & \multicolumn{1}{|c|}{ Uraian } & $\begin{array}{c}\text { Hasil Tes Prestasi Belajar Siswa } \\
\text { Siklus II }\end{array}$ \\
\hline 1 & Nilai Tertinggi & 96,92 \\
\hline 2 & Nilai Terendah & 55,38 \\
\hline 3 & Rata-Rata & 80,7 \\
\hline 4 & Ketuntasan Belajar & $80,9 \%$ \\
\hline
\end{tabular}


Dapat kita simpulkan dari data diatas secara kualitatif bahwa rata-rata dari tes prestasi belajar siswa dalam memahami isi teks bahasa Inggris materi teks Formal Letter dan Discussion di siklus II adalah 80,7. Untuk nilai tertinggi 96,92, sedangkan nilai terendah 55,38. Bisa kita lihat juga prosentase tidak tuntas sebesar 19,1\% atau 4 siswa tidak tuntas, sedangkan prosentase ketuntasan telah mencapai 80,9\% atau 17 siswa telah tuntas. Ini berarti kriteria ketuntasan klasikal telah tercapai. Untuk hasil observasi keterampilan berpikir kritis dari guru dan kolaborator didapat hasil sebagai berikut:

Tabel 5 Hasil Analisis Keterampilan Berpikir Kritis Siswa Siklus II

\begin{tabular}{|c|c|c|c|c|}
\hline $\begin{array}{c}\text { Hasil } \\
\text { Analisis }\end{array}$ & Frekuensi & Skor & $\%$ & Skor Tengah x Frekuensi \\
\hline TINGGI & 18 & $8-10$ & 85,7 & $9 \times 18=162$ \\
\hline SEDANG & 1 & $4-7$ & 0,1 & $5,5 \times 1=5,5$ \\
\hline RENDAH & 2 & $1-3$ & 0,2 & $2 \times 2 \quad=4$ \\
\hline \multicolumn{3}{|c|}{ JUMLAH } & $\mathbf{1 7 1 , 5}$ \\
\hline \multicolumn{3}{|c|}{ KATA- RATA } & $\mathbf{8 , 1 6 6}$ \\
\hline
\end{tabular}

Dari data keterampilan berpikir kritis siswa siklus II diatas, kita memperoleh data sebagai berikut: Siswa dengan keterampilan berpikir kritis kategori tinggi sebanyak 18 siswa atau 85,7\%; Siswa dengan keterampilan berpikir kritis kategori sedang sebanyak 1 siswa atau $0,1 \%$; Siswa dengan keterampilan berpikir kritis kategori rendah sebanyak 2 siswa atau 0,2\%; Rata-rata yang telah dicapai dalam siklus II untuk keterampilan berpikir kritis siswa sebesar 8,166 . Dengan jumlah rata-rata 8,166 maka keterampilan berpikir kritis siswa termasuk dalam kategori tinggi.

Peneliti dan kolaborator mengadakan diskusi refleksi di akhir siklus II. Keduanya sepakat bahwa penerapan model pembelajaran Examples Non Examples terbukti meningkatkan keterampilan berpikir kritis dan prestasi belajar siswa. Peneliti hanya merubah kelompok diskusi besar menjadi kelompok kecil. Perubahan ini telah meningkatkan keterampilan berpikir kritis dan prestasi belajar siswa dalam memahami isi teks Bahasa Inggris. Hal ini berdasarkan data kemampuan keterampilan berpikir kritis siswa siklus II telah mencapai $85,7 \%$ atau 18 siswa memiliki kemampuan keterampilan berpikir kritis kategori tinggi dalam pembelajaran. Selain itu juga meningkatkan prestasi belajar siswa, karena dari data tes prestasi belajar siswa siklus II menunjukkan perolehan nilai rata-rata sebesar 80,66 dan prosentase ketuntasan belajar siswa 80,9\% atau 17 siswa telah tuntas belajar, sehingga dari data tersebut dapat dikatakan ketuntasan belajar siswa telah mencapai indikator keberhasilan yaitu sebesar $80 \%$.

\section{B. Pembahasan}

Pada tahap pra siklus, peneliti melakukan pengamatan dengan bertujuan untuk mengetahui keadaan awal proses keterampilan berpikir kritis siswa dan prestasi belajar pada mata pelajaran bahasa Inggris khusunya materi memahami teks bahasa Inggris sebelum menerapkan model pembelajaran Examples Non Examples. Kondisi awal atau pra siklus ini dijadikan sebagai bahan melaksanakan tindakan kelas pada siklus I dan II. Setelah data awal siklus didapatkan, peneliti merencanakan tindakan dengan memberikan contoh berupa gambar agar memudahkan siswa dalam memahami materi tentang teks Bahasa Inggris ditiap siklus. Model pembelajaran yang paling tepat adalah Examples Non Examples sesuai dengan pendapat Rochyandi (dalam Ibrahim, 2002) model pembelajaran kooperatif tipe Examples 
Non Examples adalah tipe pembelajaran yang mengaktifkan siswa dengan cara guru menempelkan contoh gambar-gambar yang sesuai dengan tujuan pembelajaran dan gambar lain yang relevan dengan tujuan pembelajaran, kemudian siswa disuruh untuk menganalisisnya dan mendiskusikan hasil analisisnya sehingga siswa dapat membuat konsep yang esensial.

Untuk lebih memaksimalkan hasilnya, peneliti juga menerapkan diskusi kelompok agar semua siswa dapat terlibat dalam pembelajaran, karena menurut Usman dalam Suhana (2008: 94) diskusi kelompok merupakan suatu proses yang teratur yang melibatkan sekelompok orang dalam interaksi tatap muka yang informal dengan berbagai pengalaman atau informasi, pengambilan kesimpulan atau pemecahan masalah. Oleh karena itu, peneliti ketika melakukan tindakan didalam kelas sebagai guru mata pelajaran, membagi siswa menjadi beberapa kelompok besar yang terdiri dari 5 siswa ditiap kelompok. Penerapan diskusi kelompok ini agar siswa mampu mengeluarkan ide kritis mereka dalam menyerap materi memahami isi teks bahasa Inggris.

Dari data yang didapat di awal siklus (pra siklus) dan siklus I model pembelajaran Examples Non Examples telah terbukti memberikan pengaruh terhadap peningkatan keterampilan berpikir kritis dan prestasi belajar siswa. Dari hasil analisis keterampilan berpikir kritis siswa di pra siklus dan siklus I peningkatan itu ditunjukkan dalam bentuk tabel dibawah ini:

Tabel 6 Perbandingan Analisis Keterampilan Berpikir Kritis Siswa Pra Siklus dan Siklus I

\begin{tabular}{|c|c|c|c|c|c|}
\hline No & $\begin{array}{c}\text { Keterampilan } \\
\text { Berpikir Kritis }\end{array}$ & $\begin{array}{c}\text { Pra } \\
\text { Siklus }\end{array}$ & $\%$ & Siklus I & $\%$ \\
\hline 1 & Tinggi & 5 & 23,8 & 13 & 62 \\
\hline 2 & Sedang & 3 & 14,2 & 3 & 14,2 \\
\hline 3 & Rendah & 13 & 62 & 5 & 23,8 \\
\hline
\end{tabular}

Dari tabel diatas kita tahu bahwa siswa yang menunjukkan keterampilan berpikir kritis dengan kategori tinggi didalam kelas ketika pra siklus sejumlah 5 siswa naik menjadi 13 siswa. Sedangkan siswa dengan keterampilan berpikir kritis kategori sedang berjumlah sama yaitu 3 siswa. Tetapi dari pra siklus dan siklus I siswa dengan keterampilan berpikir kritis kategori rendah menurun jumlahnya dari 13 siswa menjadi 5 siswa. Setelah dilakukan perbaikan dalam model pembelajaran dan metode dsikusi kelompok, terlihat pula ada peningkatan dalam prosentase ketuntasan belajar dan rata-rata tes prestasi belajar siswa dari pra siklus ke siklus I. Hal ini berdasarkan hasil data perbandingan analisis tes prestasi belajar siswa pra siklus dan siklus I yang tercantum dalam tabel berikut ini:

Tabel 7 Perbandingan Analisis Tes Prestasi Belajar Siswa Pra Siklus dan Siklus I

\begin{tabular}{|c|c|c|c|}
\hline No & Prestasi Belajar Siswa & Pra Siklus & Siklus I \\
\hline 1 & Nilai Tertinggi & 88 & 95,38 \\
\hline 2 & Nilai Terendah & 35 & 40,00 \\
\hline 3 & Nilai Rata-Rata & 67,86 & 72,7 \\
\hline 4 & Ketuntasan Belajar & $29 \%$ & $57,2 \%$ \\
\hline
\end{tabular}


Data di atas sangat terlihat kalau nilai yang didapat siswa juga sangat kompetitif. Nilai tertinggi di pra siklus adalah 88 sedangkan di siklus I naik menjadi 95,38. Untuk nilai terendah pra siklus 35 sedangkan di siklus I menjadi 40,00. Rata-rata dari tes pra siklus dari 67,86 mengalami kenaikan sebesar 4,84 menjadi 72,7 meskipun prosentase ketuntasan belajar yang semula dari pra siklus sebesar 29\% di siklus I baru mencapai 57,2\%. Karena adanya implementasi model pembelajaran Examples Non Examples dengan kelompok besar yang terdiri dari 5 siswa dalam setiap kelompok diskusi disiklus I ini menyebabkan keterampilan berpikir kritis dan prestasi belajar siswa meningkat walaupun belum memenuhi target ketercapaian indikator keberhasilan yaitu sebesar $80 \%$ untuk keterampilan berpikir kritis prestasi belajar siswa. Untuk memenuhi target dari indikator keberhasilan sebesar $80 \%$, maka peneliti dibantu kolaborator melakukan perbaikan dalam proses pembelajaran. Peneliti masih tetap menggunakan model pembelajaran Examples Non Examples, akan tetapi diubah dalam pengorganisasian kelompok. Dalam siklus I menggunakan kelompok besar yang terdiri dari 5 siswa disetiap kelompok, kemudian disiklus II dirubah menjadi kelompok kecil yang beranggotakan 3 siswa disetiap kelompok agar keterampilan berpikir kritis dan prestasi belajar siswa menunjukkan hasil yang maksimal. Ini sesuai dengan pendapat Robert \& William dalam Roestiyah (2012: 15) bahwa kerja kelompok merupakan kegiatan sekelompok siswa yang biasanya berjumlah kecil, yang diorganisir untuk kepentingan belajar. Ternyata perubahan ini menjadi salah satu faktor penting dalam keberhasilan pembelajaran di siklus II. Keterampilan berpikir kritis siswa meningkat, seperti yang ditunjukkan dalam grafik dibawah ini:

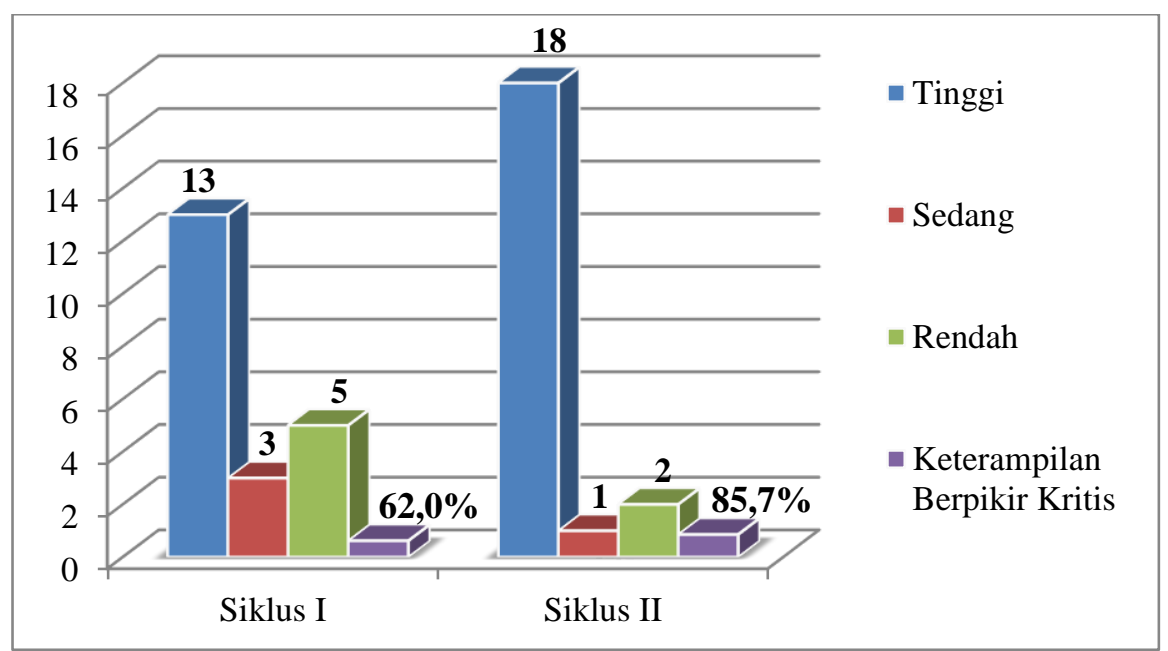

\section{Gambar 1. Grafik Perbandingan Hasil Analisis Keterampilan Berpikir Kritis Siswa Siklus I dan Siklus II}

Berdasarkan grafik diatas, siswa yang memiliki kategori tinggi dalam keterampilan berpikir kritis didalam kelas ketika siklus I sejumlah 13 siswa naik menjadi 18 siswa disiklus II. Ini artinya hampir semua siswa menunjukkan keterampilan berpikir kritisnya didalam kelas. Hanya 3 siswa dengan kategori rendah dan sedang dalam berpikir kritis. Keterampilan berpikir kritis siswa meningkat dari $62,0 \%$ menjadi $85,7 \%$. Kriteria Keberhasilan perbaikan pembelajaran ini bukan hanya terdapat pada peningkatan keterampilan berpikir kritis siswa semata tetapi juga peningkatan dalam nilai prestasi belajar siswa. Kita dapat lihat dari grafik berikut: 


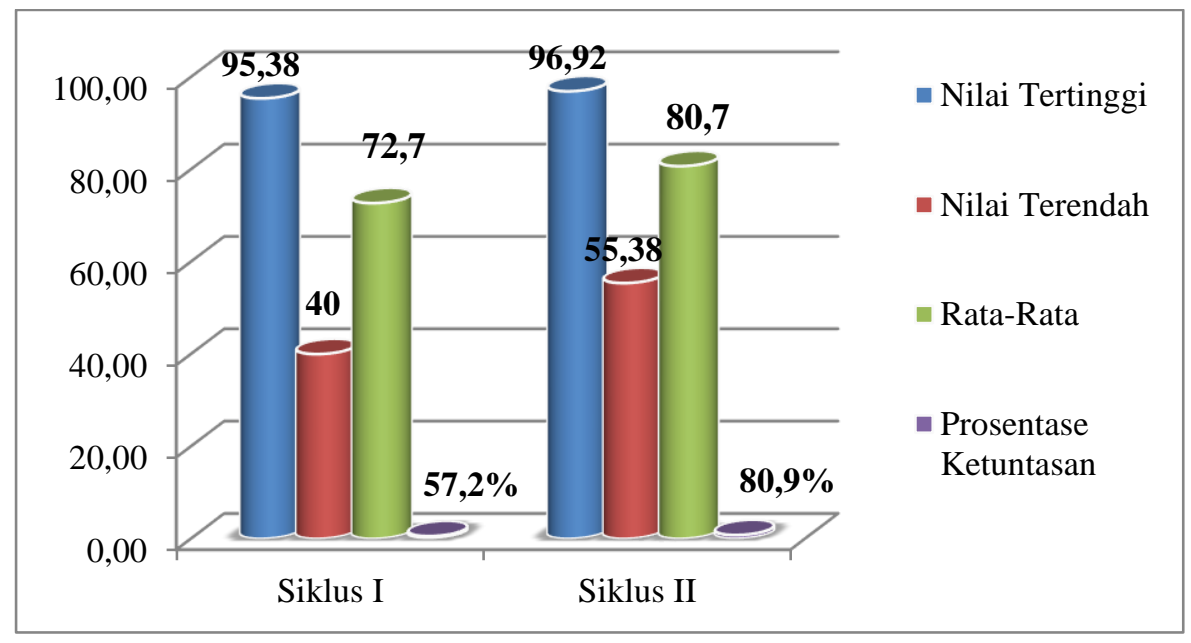

\section{Gambar 2. Grafik Perbandingan Analisis Tes Prestasi Belajar Siswa Siklus I dan Siklus II}

Grafik diatas menerangkan bahwa prestasi belajar siswa dalam memahami isi teks bahasa Inggris mengalami peningkatan rata-rata kelas disiklus I yaitu dari rata-rata 72,7 disiklus II menjadi 80,7. Walau demikian masih ada 4 siswa yang nilainya belum mencapai batas ketuntasan minimal. Namun prosentase ketuntasan dari siklus I yang semula hanya $57,2 \%$ meningkat secara signifikan menjadi $80,9 \%$. Hal ini berarti indikator keberhasilan prestasi belajar $80 \%$ telah terlampaui. Dari hasil tersebut peneliti tidak melanjutkan perbaikan ke siklus selanjutnya.

\section{PENUTUP}

Berdasarkan hasil analisis dan pembahasan, maka dapat disimpulkan bahwa tindakan perubahan metode mengajar konvensional ceramah digantikan dengan implementasi model pembelajaran Examples Non Examples dan merubah teknik kelompok diskusi siswa dari kelompok besar menjadi kelompok kecil dapat meningkatkan keterampilan berpikir kritis dan prestasi belajar siswa dalam memahami isi teks bahasa Inggris bagi siswa kelas XII IPA 1 SMAN 1 Purwanegara semester 1 tahun pelajaran 2018/2019. Peningkatan itu dapat dilihat dari hasil observasi maupun tes yang telah dilakukan oleh peneliti. Keterampilan berpikir kritis siswa yang semula di awal siklus hanya 23,8\% meningkat di akhir siklus menjadi $85,7 \%$. Sedangkan hasil prestasi belajar siswa secara signifikan juga meningkat dari $29 \%$ dengan rata-rata 67,86 di awal siklus menjadi $80,9 \%$ diakhir siklus dengan nilai rata-rata 80,7 . Model pembelajaran ini telah terbukti mampu mengatasi masalah dalam proses belajar mengajar, oleh karena itu peneliti berharap guru mata pelajaran yang lain dapat menggunakan model pembelajaran ini untuk diterapkan pada mata pelajaran masing-masing dan sebaiknya pihak sekolah menyediakan fasilitas yang mendukung guru untuk dapat mengimplementasikan model pembelajaran tersebut didalam kelas.

\section{DAFTAR PUSTAKA}

Chotimah, H dan Dwitasari, Y. (2007). Model-Model Pembelajaran untuk PTK. Malang: SMA Lab.UM

Ibrahim, Muslimin, dkk. (2002). Pembelajaran Kooperatif. Surabaya: University Press

Kurniadi, Hary. (2010). Model-Model Pembelajaran Examples Non Examples.

Kurniasih, Imas, dkk. (2015). Ragam Pengembangan Model Pembelajaran. Jakarta: Kata Pena

Melvita, Santi. (2009). Pengaruh Strategi Pembelajaran dan Gaya belajar terhadap hasil belajar Bahasa Inggris di SMA Negeri 4 Banda Aceh. Masters Thesis. UNIMED. https://digilib.unimed.ac.id/eprint/2617 
Mulyasa, E. (2011). Menjadi Guru Profesional: Menciptakan pembelajaran Kreatif dan Menyenangkan. Bandung: PT Remaja Rosda Karya

Paul, R \& Elder, L. (2008). Miniatur Guide to Critical Thinking Concepts and Tools. Dillon Beach: Foundation for Critical Thinking Press.

Pustaka Bahasa Departemen Pendidikan Nasional. (2001). Kamus Besar Bahasa Indonesia. Jakarta: Balai Pustaka

Roestiyah. (2012). Strategi Belajar Mengajar. Jakarta: Rineka Cipta

Suhana, Cucu. (2008). Kosep Strategi Pembelajaran. Bandung: PT Refika Aditama

Sunarto. (2012). Pengertian Prestasi Belajar. Jakarta: Fasilitator Idola.

Suwarna. (2006). Pengajaran Mikro. Yogyakarta: Tiara Wacana. 